ORIGINAL ARTICLE

AFRICAN JOURNAL OF CLINICAL AND EXPERIMENT AL MICROBIOLOGY SEPTEMBER 2013 ISBN 1595-689X VOL14 No.3 AJCEM/1322

COPYRIGHT 2013 http:

http://www.ajol.info/journals/ajcem

AFR. J. CLN. EXPER. MICROBIOL. 14(3): 120-126 http:/ / dx.doi.org/10.4314/ajcem.v14i3.1

\title{
PREVALENCE AND IMMUNE STATUS OF HIV/HBV CO-INFECTED PREGNANT WOMEN
}

Lar, ${ }^{1}$ P. M.,, Pam, ${ }^{1}$ V. K., Christopher, ${ }^{1 P}$. B., ${ }^{2}$ Gwamzhi, L. \& Mawak, ${ }^{1}$ J. D.

${ }^{1}$ Department of Microbiology, Faculty of Natural Sciences, University of Jos, Nigeria. PMB 2084, Jos. ${ }^{2}$ Department of Medicine, Jos University Teaching Hospital, JUTH

Correspondence: Dr Patricia Lar; 2348039665806; larp1000ng@yahoo.com

\begin{abstract}
HIV/HBV co-infection places patients at high risk of liver-related morbidity and mortality and the interaction of the two viruses can further complicate treatment. Pregnant women are especially at high risk for increased morbidity and mortality due to infection, and information about HIV/HBV co-infection in pregnant women is scanty. This study examined the occurrence of HBV antibodies in HIV-1 positive pregnant women and the relationship to Ante-retroviral therapy (ART) and other demographic characteristics. Blood samples were collected from 135 HIV pregnant positive women who were either on ART or Not, from May - June, 2008 at the Jos University Teaching Hospital (JUTH) and the Plateau State Specialist Hospital (PSSH). Presence of hepatitis B surface (HBsAg) antigen in serum was determined using Antec strips (Antec diagnostics UK) and their immunologic status were determined by measuring the $\mathrm{CD}_{4}{ }^{+}$counts using SL_3 cyFlow counter (Partec, Germany) . Sixteen 16 (11.8\%) of the women examined were seropositive for Hepatitis B virus. Occupation was significantly associated with the prevalence of the hepatitis co-infection in the population examined $(8.8 \%$ of house wives and $5.5 \%$ of business women had co-infection, $\mathrm{p}<0.05)$. The immunologic status $\left(\mathrm{CD}_{4}{ }^{+}\right.$of most of the $\mathrm{HIV} / \mathrm{HBV}$ co-infected pregnant women $\left(81.5 \%\right.$ ) was low (below $300 \mathrm{cells} / \mathrm{mm}^{3}$ ) although all were on Anti retroviral therapy. The $11.8 \%$ prevalence rate reported in this study confirms the endemicity of HBV / HIV co-infection in Nigeria, and this supports the calls for screening for Hepatitis $B$ as a routine in antenatal care.
\end{abstract}

Keywords: HIV, Hepatitis, Co-infection, $\mathrm{CD}_{4}$, Pregnant women

\section{INTRODUCTION}

Of the 33.3 million people currently living with HIV/AIDS, 68\% reside in sub-Saharan Africa (1). HIV/AIDS weakens a person's ability to fight infections; HIV-infected people are three to six times more likely to develop a chronic or long-term hepatitis B infection because of their weakened immune systems than individuals without HIV (2). Approximately $5 \%-10 \%$ of $\mathrm{HIV}$-infected persons also have chronic HBV infection, defined as testing positive for HBsAg for more than 6 months.

An estimated 400 million people are infected with Hepatitis B virus (HBV) with the majority of cases occurring in regions of Asia and Africa where the virus is endemic. In these continents up to $70 \%$ of adults show serologic evidence of current or prior infection and 8 to $15 \%$ have chronic HBV infection (2). Hepatitis B virus (HBV) is the most common cause of serious liver infection; it causes transient and chronic infections of the liver. Clinical presentation of Hepatitis B ranges from subclinical to symptomatic hepatitis and, in rare instances, fulminant hepatitis ( $\left.{ }^{3}\right)$. HBV and HIV have common characteristics such as transmission routes (vertical, parenteral, and sexual), and the propensity to establish chronic infections which are often difficult to treat with currently available anti-viral agents
$(4,5,6)$. HIV/HBV co- infection is associated with increased liver related morbidity and mortality. The pathogenesis and clinical manifestations of both are due to the interaction of the virus and the host immune system (7). The immune system attacks hepatitis B virus and causes liver injury. Activated CD4+ and CD8+ lymphocytes recognize various HBV-derived peptides located on the surface of the hepatocytes, and an immunologic reaction occurs. Impaired immune reactions, (such as cytokine release, antibody production) or relatively tolerant immune status results in chronic hepatitis (8). The immune suppression caused by HIV infection accelerates the course of liver disease caused by chronic HBV infection and results in increased mortality compared to HIV monoinfected patients (9).

Interferon does not appear to adversely affect the embryo or fetus. However, the data is limited, and the potential benefits of interferon use during pregnancy should clearly outweigh possible hazards $(10,11)$. Lamivudine used in combination with zidovudine caused pronounced and sustained increases in CD4-cell counts and reductions in HIV1 viral load in four separate studies, done in both previously antiretroviral untreated and pretreated HIV-1-positive patient Interestingly, lamivudine is also used to treat hepatitis B infections $(12,13)$. HBV replication has been proven to be inhibited by 
lamivudine in $86.4 \%$ (95\% CI, 75.7-93.6) of HIVHBV-coinfected patients $(14,15)$. Chronic HBV does not substantially alter the progression of HIV infection and does not influence HIV suppression or CD4+ cell responses following ART initiation $(16,17)$. Initial data do not suggest that Lamivudine is teratogenic (18). Lamivudine has been used in the latter half of pregnancy in attempt to prevent perinatal transmission of hepatitis B virus infection with mixed success (19). Mother to child transmission of HIV and HBV occurs often either in utero or through exposure to blood or blood contaminated fluids at or around birth. Such perinatal transmission is believed to account for 35$50 \%$ of carriers (18). Perinatal childhood infection of $\mathrm{HBV}$ is characterised by symptomlessness, but places carriers at a high risk of developing chronic disease (3). It has also been shown that vertical transmission of hepatitis B virus occurs in about $10 \%$ of neonates when the infection occur in the first trimester and in $60 \%$ to $90 \%$ of babies in the third trimester (20). Screening for HBsAg is routine in pregnancy in most developed countries, 122 Colleges of Obstetrics and Gynecology worldwide screen pregnant women for Hepatitis $(21,22)$. In Nigeria, HIV is routinely tested for pregnant women but not HBV despite their overlapping routes of transmission. Sero-prevalence studies on HBsAg in Nigeria show that the prevalence of the infection in pregnant women range from $2-15 \%(23$, $24,25)$

The prevalence of hepatitis B virus (HBV) infections in Nigeria have been reported as $17.1 \%$ among female sex workers in Nigeria and $11.9 \%$ in HIV infected persons $(26,27)$. Imade et al., had done a study in 2004 and reported a prevalence of $11.5 \%$ but did not check the immune status of the women in Jos and Oladokun et al., reported a prevalence rate of $8.9 \%$ co-infection rate among pregnant women in Ibadan $(28,29)$. This study was carried out to determine the prevalence of hepatitis B among HIV infected pregnant women in Jos and also to establish the effect of co-infection on their immunological status.

\section{MATERIALS AND METHODS}

\section{Study Design}

A cross sectional study was carried out among HIV positive pregnant women at the Jos University Teaching Hospital (JUTH) and Plateau State Specialist Hospital (PSSH) between the months of May and June 2008. Blood samples were collected from one hundred and thirty five (135) of the subjects and Ethical clearance for this study was obtained from both the JUTH Institutional Health Research Ethical Committee and PSSH health research ethical committee. Patients were approached with a letter introducing the subject and their consent was obtained by the subject's signature on the questionnaire given to them. Laboratory numbers was indicated on the questionnaires and same number on the sample bottle to protect patients' identity. The outcome of this finding was referred to the clinician for extra attention and care. The samples were then tested for HBV surface antigens and $\mathrm{CD}_{4}+$ counts.

\section{Sample Collection}

A total of 135 blood samples (The sample size was derived using the formula for sample size calculation: $\mathrm{N}=\mathrm{z}^{2} \mathrm{pq} / \mathrm{d}^{2}$ (where $\mathrm{z}=$ Standard normal deviation at 1.96 (which corresponds to 95\% confidence interval; $p=$ Prevalence of Hepatitis B surface antigen in ante-natal women in Nigeria from previous studies; $\mathrm{q}=1-\mathrm{p}$; and $\mathrm{d}=$ degree of accuracy / precision expected $=0.05$ ). were collected from HIV positive pregnant women by venipuncture. $5 \mathrm{mls}$ of blood was collected aseptically and emptied into sterile vacutainer tubes and labelled. The uncoagulated blood was allowed to separate into serum at room temperature.

\section{Detection of HbsAG Using Antec Strips}

The serum was collected into clean containers and used to test for hepatitis B surface antigen $\mathrm{HbsAg}$ using the one step disposable Hepatitis B surface antigen test strips (Antec diagnostics; United Kingdom). The test procedure was carried out following manufacturer's instructions and the results interpreted and recorded accordingly.

\section{Determination of Absolute CD4+ count}

The blood was placed on a mixer in order to get a homogenous mixture. All the test tubes were labeled accordingly. Monoclonal antibody PE, $20 \mu \mathrm{l}$ was pipetted into a tube; $20 \mu \mathrm{l}$ of the patient's blood sample was added. The mixture was thoroughly mixed and incubated in the dark for 15 minutes. No-lyse phosphate buffered saline (PBS) dilution buffer, $800 \mu l$ was added and the mixture connected to a cyflow counter (Partec, Germany) for analysis.

\section{CD4+ \% Enumeration}

Monoclonal antibody $\mathrm{CD}_{4}+(\mathrm{CD} 4 \mathrm{MAb} \mathrm{PE})$ and $\mathrm{CD}_{45}+(\mathrm{CD} 4 \mathrm{MAb} \mathrm{PE}), 10 \mu \mathrm{l}$ was pipette into rhoren tubes, $20 \mu$ l of the patient's blood samples was added. The mixture was thoroughly mixed and incubated in the dark for 15 minutes at room temperature. No-lyse dilution buffer 1 and 2, 400 $\mu 1$ was added just before reading and connected to SL_3 cyflow (Partec, Germany) and analysed.

\section{Interpretation of Immunologic Status Result}

The CD4+count of normal patients (healthy immune competent, HIV negative persons in Nigeria) lie between 547-1327 cells/ $\mathrm{mm}^{3}$. Any $\mathrm{CD}_{4}+$ Count within the range $200-500$ cells $/ \mathrm{mm}^{3}$ suggests that the person is immune compromised (some damage has been done to the immune system) (30). 


\section{RESULTS}

\section{Prevalence Rates}

Out of the 135 sera collected from HIV infected pregnant women examined, 16 of them were seropositive for Hepatitis B representing $11.8 \%$ of the total (Table 1). Women between the age ranges 36-40 had the highest rate of co-infection, this is not statistically significant $\left(X^{2}=0.074, P=0.05 \mathrm{df}=40.05\right)$, while women between the age range $16-20$ had no co-infection (Table 1).

Association of HIV/HBV co-infection in Pregnant Women and Treatment, Occupational and Educational Characteristics

The occupation of the women examined showed that housewives and business women had higher rates of HIV/HBV co-infection $(8.8 \%$ and $5.5 \%$ respectively), occupation is significantly associated with co-infection $\left(\mathrm{X}^{2}=0.035 \mathrm{P}=0.05 \mathrm{df}=4\right) \quad$ With respect to educational level, pregnant women who were educated only to secondary level had the highest prevalence of co-infection $(4.4 \%)$, those with no formal education had the lowest prevalence rates $(0.7 \%)$ but the difference in the prevalence rates was not statistically significant in women with secondary education compared to the rest $\left(\chi^{2}=\right.$ $0.545 \mathrm{P}=0.05 \mathrm{df}=3$ ) (Table 2). Among the 135 women examined $18.5 \%$ of those who had HIV alone were on antiretroviral therapy (ART) while $6.7 \%$ of those with $\mathrm{HIV} / \mathrm{HBV}$ co-infection were on ART.
TABLE 1; AGE RANGE AND PREVALENCE DISTRIBUTION OF HIV/HBV CO-INFECTED IN HIV POSITIVE PREGNANT WOMEN

\begin{tabular}{llll}
\hline $\begin{array}{l}\text { AGE } \\
\text { RANGE }\end{array}$ & $\begin{array}{l}\text { NUMBER } \\
\text { EXAMINED }\end{array}$ & $\begin{array}{l}\text { NUMBER } \\
\text { HBsAg } \\
\text { Positive }^{\beta}\end{array}$ & $\begin{array}{l}\% \\
\text { POSITIVE } \\
\text { FOR } \\
\text { HIV/HBV }\end{array}$ \\
\hline $16-20$ & 10 & 0 & 0.0 \\
$21-25$ & 31 & 1 & 0.7 \\
$26-30$ & 48 & 5 & 3.7 \\
$31-35$ & 28 & 4 & 3.0 \\
$36-40$ & 18 & 6 & 4.4 \\
TOTAL & 135 & 16 & 11.8 \\
\hline
\end{tabular}

$\%=$ Percentage $; *=$ Number of pregnant women examined; $\beta=$ Number of pregnant women positive for HBsAg; $\chi^{2}=0.074 \mathrm{P}=0.05 \mathrm{df}=4$

Immunologic Status

The CD4+ counts of the women with HIV/HBV coinfection were lower than those with HIV alone but there was no association between co-infection and the immunologic status of the pregnant women $\left(X^{2}=0.297 \mathrm{P}=0.05 \mathrm{df}=5\right)$. But $81.2 \%$ of the women with $\mathrm{HIV} / \mathrm{HBV}$ co-infection had $\mathrm{CD} 4+$ values below 300 cells $/ \mathrm{mm}^{3}$ (Table 3 ).

TABLE. 2; TREATMENT, OCCUPATIONAL AND EDUCATIONAL CHARACTERISTICS OF HIV/HBV CO-INFECTED PREGNANT WOMEN IN JOS

\begin{tabular}{|c|c|c|}
\hline CHARACTERISTICS & HIV (\%) & HIV/HBV (\%) \\
\hline \multicolumn{3}{|l|}{ Treatment Characteristics } \\
\hline${ }^{*}$ ART & 25 (18.5) & $9(6.7)$ \\
\hline $\begin{array}{r}\text { NON-ART } \\
\mathbf{n}=135\end{array}$ & $94(69.6)$ & $7(5.2)$ \\
\hline \multicolumn{3}{|l|}{ Occupational Characteristics } \\
\hline BUSINESS & $7(7.52)$ & $5(5.5)$ \\
\hline HOUSE WIFE & $30(33.0)$ & $8(8.8)$ \\
\hline SELF EMPLOYMENT & 17 (18.7) & $1(1.1)$ \\
\hline CIVIL SERVANT & $12(13.1)$ & 1 (1.1) \\
\hline $\begin{array}{l}\text { PRIVATE EST ABLISHMENT } \\
\mathrm{n}=91 \chi^{2}=0.035 \mathrm{P}=0.05 \mathrm{df}=4\end{array}$ & $10(11.0)$ & $0(0.0)$ \\
\hline \multicolumn{3}{|l|}{ Educational Characteristics } \\
\hline PRIMARY & $24(24.0)$ & $5(5.0)$ \\
\hline SECONDARY & $30(30.0)$ & $6(6.0)$ \\
\hline TERTIARY & $29(29.0)$ & $4(4.0)$ \\
\hline $\begin{array}{l}\text { NO FORMAL EDUCATION } \\
n=100 \quad \chi^{2}=0.545 \quad \mathrm{P}=0.05 \mathrm{df}=3\end{array}$ & $1(1.0)$ & $1(1.0)$ \\
\hline
\end{tabular}


TABLE 3: IMMUNOLOGIC CHARACTERISTICS OF HIV/HBV CO-INFECTED PREGNANT WOMEN

\begin{tabular}{|c|c|c|c|}
\hline $\begin{array}{l}\mathrm{CD}_{4} \text { Count } \\
\text { Range (cells/mm } / \mathrm{mm}^{3}\end{array}$ & $\begin{array}{l}\text { Number Subjects } \\
\text { Examined }\end{array}$ & HIV Positive & HIV/HBV Co-infected \\
\hline $0-100$ & 16 & 11 & 5 \\
\hline $101-200$ & 9 & 5 & 4 \\
\hline 201-300 & 13 & 9 & 4 \\
\hline $301-400$ & 13 & 12 & 1 \\
\hline 401-500 & 4 & 3 & 1 \\
\hline $501-600$ & 0 & 0 & 0 \\
\hline $601-700$ & 1 & 0 & 1 \\
\hline TOTAL & $56^{*}$ & 40 & 16 \\
\hline
\end{tabular}

\section{DISCUSSION}

$\mathrm{HBV}$ infection in pregnancy is emerging as an increasingly important issue, although more attention has been given to $\mathrm{HCV}$ co-infection because of the higher possibility of developing chronic disease, HBV prevalence rates have been reported to be higher than $\mathrm{HCV}$ rates in Nigeria $(31,32)$. In this study, $11.8 \%$ of the pregnant women population examined was found positive for $\mathrm{HIV} / \mathrm{HBV}$ co-infection. In 2004 the rates of $\mathrm{HIV} / \mathrm{HBV}$ co-infection among pregnant women in Jos was reported as $11.5 \%$, this rate is almost similar to that reported by this study, suggesting that the situation with HIV/HBV co-infection in our environment has not changed (33).

Other Nigerian studies have reported different prevalence rates. In a study in the Federal Capital Teritory (FCT), Abuja, Nigeria the prevalence rate of $\mathrm{HIV} / \mathrm{HBV}$ co-infection was reported as $7.1 \%$, in Yola North East Nigeria, a prevalence rate of $8.2 \%$ was reported among pregnant women. Adesina et al., reported a prevalence rate of $8.9 \%$ among HIV infected pregnant women $(34,35,36)$. Similarly, in other parts of Africa, varying prevalence rates have been reported; Chasela reported a prevalence rate of $10.4 \%$ among pregnant women in Malawi, in Uganda $4.1 \%$ was reported among HIV positive pregnant women and a rate of $2.4 \%$ in Rwanda also among HIV infected pregnant women $(37,38)$. In Europe, a prevalence rate of $4.9 \%$ has been reported among HIV infected pregnant women and a low coinfection rate of $1.5 \%$ was reported among pregnant women in America $(39,40)$. Jos is thus hyperendemic area for Hepatitis B virus infection, according to WHO classification for Hepatitis B endemicity $(41,42)$.

Age is not an important factor related to the prevalence of hepatitis B infection in HIV infected women as revealed in this study. The difference in HIV/HBV co-infection among the various age groups shows that women within the age range 3640 had higher prevalence rates of $\mathrm{HIV} / \mathrm{HBV}$ coinfection than women within other age brackets. Eke et al., and Habiba et al., however, reported higher prevalence rates in pregnant women within the age brackets of 20-24 and 25-35 years respectively $(43,44)$. This deviation may have been due to the size of the population studied, a higher population size could change the dynamics.

Occupation was found to be associated with the prevalence of co-infection, among house wives and business women. This is similar to the report of Mohammadi et al., who reported significant association between HIV/HBV co-infection among house wives compared to other occupations in Iran (45).

Educational background was not associated with co-infection rates in our study, $(\mathrm{P}>0.05)$, and this was the observation of Eke et al. also, who reported no association between HBV infection and educational level among individuals in low resource settings in Nigeria (43). Ezegbudo et al., however found an association between educational background and HIV/HBV infection in pregnant women in Anambra state Nigeria (46). 
With respect to the immune status of the study subjects, although the $\mathrm{CD}_{4}+$ counts of the women with co-infection were below 300 cells $/ \mathrm{mm} 3$ there was no statistically significant association between HIV/HBV co-infection and the immune status of the pregnant women. Most studies have reported reduced $\mathrm{CD} 4+$ count in $\mathrm{HIV} / \mathrm{HBV}$ co-infected women when compared with monoinfected women. Otegbayo et al., observed lower CD4+

\section{REFERENCES}

1. "Worldwide AIDS \& HIV Statistics". AVERT. 31 December2009;http://www.avert.org/worldstats.h tm. Retrieved 26 January 2011

2. Hoffman CJ, Thio CL. Clinical implications of HIV and hepatitis B co-infection in Asia and Africa. Lancet Infect Dis 2007, 7; 402-409.

3. Chan HLY, Lok ASF. Hepatitis B in adult-a clinical perspective. Clin Liver Dis 1999; 3(2): 291307.

4. Dabis F and Ekpini ER., HIV-1/AIDS and maternal and child health in Africa. Lancet. 2002 Jun 15;359(9323):2097-104.

5. Kamiya N. The mechanisms of action of antivirals against Hepatitis B virus infection. J Antimicrobial Chem 2003; 51: 1085-1089

6. Drosten C, Nippraschk T, Manegold C et al. Prevalence of hepatitis B virus DNA in anti-HBCpositive/HBsAg-negative sera correlates with $\mathrm{HCV}$ but not HIV serostatus. J Clin Virol., 2004; 29: 59-68.

7. Poonam Sharma. Hepatitis B. e-Medicine. 2008.

Available at: (ㅇ) http:/ / www

Emedicine.com/ped/Topic978.Htm. Accessed May 5th, 2008.

8. Cooley L, Sasadeusz J. Clinical and Virological aspects of Hepatitis B co-infection in individuals infected with human immunodeficiency virus type1. J Clin Virol 2003; 26: 185-193

9. Omland LH, Weis N, Skinhøj P, Laursen A, Christensen PB, Nielsen HI, Møller A, Engsig F, Sørensen HT, Obel N. Impact of hepatitis B virus co-infection on response to highly active antiretroviral treatment and outcome in HIVinfected individuals: a nationwide cohort study. HIV Med. 2008 May; 9(5):300-6.

10. Briggs GG,Freeman RK, Yaffe SJ,. Drugs in Pregnancy and Lactation 7th edition,Baltimore, MD: 2005 p $836-838$

11. Ozaslan E, Yilmaz R, Simsek H, Tatar G. Interferon therapy for Acute Hepatitis C during pregnancy.Ann Pharmacother. 2002;36:1715-8.

12. Katlama C, Ingrand D, Loveday C, et al. Safety and efficacy of lamivudine-zidovudine combination therapy in antiretroviral naïve patients. JAMA 1996; 276:118-25.

13. Bartlett JA, Benoit SL, Johnson VA, et al. Lamivudine plus zidovudine compared with zalcitabine plus zidovudine in patients with HIV infection. Ann Intern Med 1996; 125:161-72.

14. Dore J, Cooper D, Barret C, et al. Dual efficacy of lamivudine treatment of human immunodeficiency virus-hepatitis B coinfected persons in a counts in HIV/HBV co-infected pregnant women in Ibadan, Nigeria (27). Forbi et al., also reported a lower CD4+ count in patients with HIV/HBV coinfection as compared with patients with HIV monoinfection, another study by Idoko et al., reported same in Jos $(47,48)$. However Hoffman et al., (49) reported that HBV does not affect CD4+ cell count in people infected with HIV.

randomized, controlled study (CAESAR). J Infect Dis 1999; 180: 607-13.

15. Hoff J, Bani-Sadr F, Gassin M, et al. Evaluation of chronic hepatitis $B$ virus (HBV) infection in coinfected patients receiving lamivudine as a component of anti-human immunodeficiency virus regimens. Clin Infect Dis 2001; 32:963-9.

16. Konopnicki D, Mocroft A, de Wit S, et al. Hepatitis B and HIV: prevalence, AIDS progression, response to highly active antiretroviral therapy and increased mortality in the EuroSIDA cohort. AIDS. 2005;19(6):593-601.

17. Hoffmann CJ, Seaberg EC, Young S, et al. Hepatitis B and long-term HIV outcomes in coinfected HAART recipients. AIDS. 2009;23(14):1881-1889.

18. Yao J L. Perinatal transmission of Hepatitis B virus infection aVd vaccination in China. Gut 1996; 38 (suppl 2): S37-8.

19. Van Zonneveld M, Van Nunen AB, Niesters HG, de Man RA, Schalm SW, Janssen HL. Lamivudine treatment during pregnancy to prevent perinatal transmission of Hepatitis B virus infection.J Viral Hepat. $2003 ; 10(4): 294-7$.

20. Bohidar NP. Hepatitis B infection in Pregnancy. Hepatitis B Annual. 2004;1(1):199-209.

21. National Institute for Health and Clinical Excellence (NICE) Ante-natal care. Routine care for healthy pregnant women. National Collaborating Center for Women's and Children's Health. 2008;62:1“454.

22. American College of Obstetricians and Gynecologists (ACOG) ACOG Practice Bulletin. 86. ACOG, Washington DC; 2007. Viral Hepatitis in Pregnancy.

23. Ezegbudo CN, Agbonlahor DE, Nwobu GO, Igwe CU, Agba MI, Okpala HO. The Seroprevalence of Hepatitis B surface antigen and Human Immunodeficiency Virus (HIV) among pregnant women in Anambra State. Shiraz EMedical Journal. 2004;5(2):1-8

24. Mbaawuaga EM, Enenebeaku MNO, Okopi JA, Damen JG. Hepatitis B virus infection (HBV) among pregnant women in Makurdi, Nigeria. African Journal of Biomedical Research. 2008;11:155-159.

25. Baba MM, Onwuka IS, Baba SS. Hepatitis B and $\mathrm{C}$ infections among pregnant women in Maiduguri, Nigeria. Central European Journal of Public Health. 1999;7(2):60-62.

26. Forbi JC, Onyemauwa N, Gyar SD, Oyeleye AO, Entonu P, Agwale SM. High prevalence of Hepatitis $B$ virus among female sex workers in Nigeria. Rev Inst Med Trop Sao Paulo. 2008 Jul-Aug;50(4):219-21. 
27. Otegbayo JA, Taiwo BO, Akingbola TS, Odaibo GN, Adedapo KS, Penugonda S, Adewole IF, Olaleye DO, Murphy R, Kanki P. Prevalence of Hepatitis B and C seropositivity in a Nigerian cohort of HIV-infected patients. Ann Hepatol. 2008 Apr-Jun;7(2):152-6.

28 Imade GE, Sagay AS, Ugwu BT, Thatcher TD, Ford RW. Sero-prevalence of Hepatitis B and Human Immunodeficiency Virus infections in pregnant women in Nigeria. Journal of Medicine in the Tropics. 2004;6(2):15-21.

29. Adesina $\mathrm{O}$, Oladokun A, Akinyemi $\mathrm{O}$, Adedokun B, Awolude O, Odaibo G, Olaleye $\mathrm{D}$,Adewole I. Human Immuno-Deficiency virus and Hepatitis B Virus Coinfection in pregnancy at the University College Hospital, Ibadan. Afr J Med Med Sci. 2010 Dec; 39(4):305-10.

30. Aina O, Dadik J, Charurat M, Amangaman P, Gurumdi S, Mang E, Guyit R, Lar N, Datong P, Daniyam C, Kanki P, Abimiku A. Referance Values of CD4T Lymphocytes in Human Immunodeficiency Virus Negative Adult Nigerians. Clin. Diagn. Lab. Immunol. 2005, April; 2(4):525- 530.

31. Piliero, P.J., Faragon, J.J. (2002). Case report. Hepatitis B virus and HIV Co-infection. AIDS Res; 12 (10): 443 - 448 - 51.

32. Buseri FI, Muhibi MA, Jeremiah ZA. Seroepidemiology of transfusion-transmissible infectious diseases among blood donors in osogbo, southwest Nigeria. Bllod Transfus. 2009 Oct; (4): 293 9.

33. Imade GE, Sagay AS, Ugwu BT, Thatcher TD, Ford RW. Sero-prevalence of Hepatitis B and Human Immunodeficiency Virus infections in pregnant women in Nigeria. Journal of Medicine in the Tropics. 2004;6(2):15-21.

34. Bassey, EB and Moses, AE and Udo, SM and Umo, AN. (2009). Parallel and overlapping Human Immunodeficiency Virus, Hepatitis $B$ and $C$ virus Infections among pregnant women in the Federal Capital Territory, Abuja, Nigeria.

35. Olokoba AB, Salawu FK, Danburam A, Olokoba LB, Midala JK, Badung LH, Olatinwo A. Hepatitis B virus infection amongst pregnant women in Northeastern Nigeria- a call for action. Niger J Clin Pract. 2011 Jan-Mar; 14(1):10-3.

36. Adesina $\mathrm{O}$, Oladokun $\mathrm{A}$, Akinyemi $\mathrm{O}$, Adedokun B, Awolude O, Odaibo G, Olaleye D, Adewole I. Human immuno-deficiency virus and hepatitis B virus coinfection in pregnancy at the University College Hospital, Ibadan. . Afr J Med Med Sci. 2010 Dec;39(4):305-10.

37. Chasela, P. Wall, E. Teshale, M. Hosseinpour, J. Drobeniuc, S. Ellington, M. Codd, W. Powderly, G. Tegha, C. Chavula, D. Kayira, P. Fitzpatrick, A. Kourtis, C. van der Horst, The UNC Project BAN Study Team.Prevalence of Hepatitis B virus (HBV) and occult $\mathrm{HBV}$ infections among pregnant women coinfected with human immunodeficiency virus type-1 (HIV-1) in Malawi: . 5th IAS conference on HIV pathogenesis, treatment and prevention. 19-22, 2009.
38. Pirillo MF, Bassani L, Germinario EA, Mancini MG, Vyankandondera I, Okong P, Vella S, Giuliano $\underline{M}$. Seroprevalence of hepatitis B and C viruses among HIV-infected pregnant women in Uganda and Rwanda. I Med Virol. 2007 ;79(12):1797-801.

39. Landes $\mathrm{M}$, Newell ML, Barlow $\mathrm{P}$, Fiore $\mathrm{S}$, Malyuta R, Martinelli P, Posokhova S, Savasi V, Semenenko I, Stelmah A, Tibaldi C, Thorne C. Hepatitis B or Hepatitis C coinfection in HIVinfected pregnant women in Europe. HIV Med. 2008;9(7):526-34.

40. Patricia Santiago-Munoz MDScott Roberts MD, MS, Jeanne Sheffield MD, Barbara McElwee BSN, RNC, WHCNP and George D. Wendel, Jr. MD . 6.3\% Prevalence of Hepatitis B And C in Pregnant Women Who are Infected With HIV . American Journal of Obstetrics and Gynecology Volume 193, Issue 3, Supplement 1, 2005, 1270-1273.

41. Mahoney FJ, Kane M. Hepatitis B vaccine. In: Plotkin SA and Orenstein WA, eds. Vaccines, 3rd ed. Philadelphia, W.B. Saunders Company, 1999:158182.

42. Viral Hepatitis Prevention Board. Universal HB immunization by 1997: where are we now?, 1998 (Fact Sheet VHPB/ 1998/2, http://hgins.uia.ac.be/esoc/VHPB/vhfs2.html).

43. Ahizechukwu C Eke, Uzoamaka A Eke, Charles I Okafor, Ifeanyichukwu U Ezebialu, and Chukwuanugo Ogbuagu . Prevalence, correlates and pattern of Hepatitis B surface antigen in a low resource setting. Virol J., 2011; 8: 12.

44. Habiba SA, Memon MA. Prevalence of Hepatitis B Infection in Pregnant Women in a Tertiary carenHospital. Infectious Disease Journal of Pakistan. 2007. pp. $35 \hat{e} €^{\prime \prime} 38$.

45. Mohammadi, M, Talei, G, Sheikhian, A, Ebrahimzade, F, Pournia, Y, Ghasemi, E, and Boroun, H, (2009). Survey of both hepatitis B virus (HBsAg) and hepatitis $\mathrm{C}$ virus (HCV-Ab) coinfection among HIV positive patients. Virol J. 6: 202.

46. Ezegbudo, CN, Agbonlahor,DE, Nwobu,GC, Igwe, CU, Agba, MI, Herbert O. Okpala, $\mathrm{HO}$, Ikaraoha, CI,( 2004) .The Seroprevalence of Hepatitis B Surface Antigen and Human Immunodeficiency Virus Among Pregnant Women in Anambra State, Nigeria. Shiraz E-Medical Journal, 5: 2

47. Forbi JC, Vaughan G, Purdy MA, Campo DS, Xia GL, Ganova-Raeva LM, Ramachandran S, Thai $\mathrm{H}$, Khudyakov YE. Epidemic History and Evolutionary Dynamics of Hepatitis B virus infection in two remote Communities in rural Nigeria. . PLoS One. 2010 Jul 19;5(7):e11615.

48. Idoko J, Meloni S, Muazu M, Nimzing L, Badung B, Hawkins C, Sankale JL, Ekong E, Murphy R, Kanki P, Thoi CL. Impact of Hepatitis B Virus Infection on Human Immunodeficiency Virus Response to Antiretroviral Therapy in Nigeria. Clin Infect Dis. $200915 ; 49(8)$ : 1268-73.

49. Hoffmann CJ, Charalambous S, Martin DJ, Innes C, Churchyard GJ, Chaisson RE, Grant AD, Fielding 
KL, Thio CL. Hepatitis B virus infection and response to antiretroviral therapy (ART) in a South African ART program. Clin Infect Dis. 2008 Dec 1;47(11):1486-9 